\title{
TRADE, COMMERCE AND ECONOMICS: INDIAN PERSPECTIVES VERSUS WESTERN THOUGHTS, DIFFERENCES AND SIMILARITIES
}

\author{
Preetham G Kamath ${ }^{* 1} \otimes$ \\ ${ }^{*}$ School of Commerce, Finance and Accountancy, Christ (Deemed to be University), India
}

DOI: https://doi.org/10.29121/ijetmr.v7.i12.2020.837

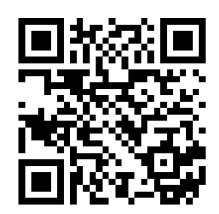

Article Citation: Preetham G

Kamath. (2020). TRADE, COMMERCE AND ECONOMICS:

INDIAN PERSPECTIVES VERSUS

WESTERN THOUGHTS, DIFFERENCES AND SIMILARITIES. International Journal of Engineering Technologies and Management Research, 7(12), 60-63.

https://doi.org/10.29121/ijetmr.v7 .i12.2020.837

Published Date: 28 December 2020

Keywords:

Perspectives

Commerce

Differences

Similarities

Economics

Thoughts

\begin{abstract}
Commerce, this has been an essential aspect of every individual's life. The history of commerce dates back to the evolution of the human race on planet earth. It all started with a barter system where give and take was the policy. As and when the human race started to evolve loopholes in the system started to grow, and slowly but steadily, complexities started growing. Commercial aspects started gaining much relevance in peoples lives. People started dividing themselves geographically and started exchanging between two distinct geographies, as and when the divisions were made, there started differences in the thoughts as to how commercial activities are ought to be conducted. While few conflicted with each other, few were drawn on similar lines to ensure smooth commercial activities. Such commercial activities slowly started forming economies of the geographies, economists who defined the way economies have to be run with their theories grew in number. This paper draws differences and similarities between thoughts that arose between Indian and western country's economists on commerce and economic activities over various time frames.
\end{abstract}

\section{INTRODUCTION}

History of Indian Commerce and Economics: Indian trade and commerce gained significant importance from the ages of Kautilya who wrote one "Arthashastra" which talks about economics and polity. Later, Mughal dynasty ruled over India and various emperors like Akbar, Tughluq took control of India's economics. India, towards its independence, also saw Gandhian economics. However, Gandhi himself was not an economist, he played a significant role in reducing salt prices and encouraged swadeshi products to generate more revenue internally and avoid British from transferring Indian money to home country in the form of taxes. Post-independence too India saw various models such as the Mahanobi's model and many more (Dasgupta, 1993). It is believed that amongst all civilizations such as Greek, Roman and Chinese. Indian civilization philosophies were more affluent and much corresponding to modern-day trade commerce and industry (Rana, 2013).

History of Western Commerce and Economics: Explorers opened up to move to countries like India and America due to the Ottoman empire's superior position. However, trade and commerce started gaining relevance only in between the $13^{\text {th }}$ and $14^{\text {th }}$ century. Western civilization was primarily hit by great famine and black death from 1290 to 1348 (Boundless, 2018). Trades also took place during wars from the ancient emperors to World War II, and soon after the World War II, western world economies decided on Bretton woods system to prevent trade

(C) 2020 The Author(s). This is an open access article distributed under the terms of the Creative Commons Attribution License, which permits unrestricted use, distribution, and reproduction in any medium, provided the original author and source are credited. 
barriers in 1946 and General Agreement on Trade and Tariffs in 1947 in Europe set up Europian Economic Community (E.E.C.) in 1957 and Europian Free Trade Association (FEAT) in 1960 (Rushton, 2004).

\section{METHODOLOGICAL APPROACH}

The current article is conceptual and derives its essence from various other research previously carried out. Thus, a review of literature plays a pivotal role in drawing the differences and similarities. The literature reviews give an idea on theoretical concepts future scope and present sources (Chandan R Honavar, 2020).

\section{REVIEW OF LITERATURE}

Table 1: Perspectives

\begin{tabular}{|c|c|c|c|}
\hline Category & Economists & Title of the Book/Article & Perspective \\
\hline Indian & Kautilya & Arthashastra & $\begin{array}{l}\text { In some cases, Artha has varied meaning, such as } \\
\text { material well-being, livelihood, and wealth of nations } \\
\text { in trade and commerce. ("The Arthashastra," 2010) }\end{array}$ \\
\hline Western & Adam Smith & Wealth of Nations & $\begin{array}{l}\text { Busy human life is intervened by something which } \\
\text { plays a vital role in progression, and that something is } \\
\text { known as invisible hands ("The Wealth of Nations," } \\
2010 \text { ) }\end{array}$ \\
\hline Indian & Thiruvalluvar & Thirukkural & $\begin{array}{l}\text { The primary cause of the economic condition of a } \\
\text { nation is rain. As crops grow because of rain, so it is } \\
\text { rain which aids as well as destroys the economy } \\
\text { (Chendroyaperumal, 2010) }\end{array}$ \\
\hline Western & David Ricardo & Works of David Ricardo & $\begin{array}{c}\text { David Ricardo believed that the price of labour in the } \\
\text { market would be at subsistence anything above or } \\
\text { below would draw the market price back ("The } \\
\text { Works of David Ricardo," 2010) }\end{array}$ \\
\hline Indian & $\begin{array}{l}\text { Dadabhai } \\
\text { Naroji }\end{array}$ & Poverty and Un-British rule & $\begin{array}{l}\text { The drain of wealth is not due to internal factors but } \\
\text { due to colonial rule (Dadabhai Naoroji, 2015) }\end{array}$ \\
\hline Western & Karl Marx & Karl Marx selected writings & $\begin{array}{c}\text { Value of a good is directly proportional to labour } \\
\text { hours spent on it ("Karl Marx," 2010) }\end{array}$ \\
\hline Indian & V.K.R.V Rao & $\begin{array}{l}\text { Investment, income and } \\
\text { the multiplier in an under- } \\
\text { developed economy }\end{array}$ & $\begin{array}{l}\text { V.K.R.V. Rao said that the Keynesian theory never } \\
\text { focused on underdeveloped economies and there is } \\
\text { always a gap between income and consumption and } \\
\text { such gap is called investment (Rao, V. K. R. V, 1952) }\end{array}$ \\
\hline Western & $\begin{array}{c}\text { John Maynard } \\
\text { Keynes }\end{array}$ & $\begin{array}{l}\text { John Maynard Keynes, The } \\
\text { economist as Saviour } \\
1920-1937\end{array}$ & $\begin{array}{l}\text { Keynes believed that there is full employment when } \\
\text { demand equals supply and that there must be } \\
\text { government expenditures to increase the demands. } \\
\text { (Skidelsky, Maynard, \& De Alcal\&amp; 1993) }\end{array}$ \\
\hline Indian & $\begin{array}{l}\text { Dr Manmohan } \\
\text { Singh }\end{array}$ & $\begin{array}{l}\text { India's Economic Reforms } \\
\text { and Development: Essays } \\
\text { for Manmohan Singh, } \\
\text { Second Edition }\end{array}$ & $\begin{array}{c}\text { Manmohan sing then F.M. believed that going global } \\
\text { and liberalizing the current economy and privatizing } \\
\text { government holdings would improve India from the } \\
\text { crisis (Isher Judge Ahluwalia, 2012) }\end{array}$ \\
\hline Western & Mark Skousen & $\begin{array}{l}\text { The Making of Modern } \\
\text { Economics: The Lives and } \\
\text { Ideas of the Great Thinkers }\end{array}$ & $\begin{array}{l}\text { Growth of the developing world happened because of } \\
\text { free trade and privatization and denationalization } \\
\text { (Skousen, M. 2016) }\end{array}$ \\
\hline
\end{tabular}

\section{SIMILARITIES}


Though economists vary from one another and their perspective varies, both Indian and Western theorists clearly understand the necessary foundation of economics. Although the Western economists came much later than the Indian economists, definitions of the economy match as both Kautilya and Adam Smith propagated that economy in brief means to say the wealth of nations. However, there are many disagreements between the driving force and demand creation in a running economy. Economists of both the school of thoughts agree that modern-day economy runs on denationalization and free trade.

\section{DIFFERENCES}

Kautilya and Adam Smith had similar views on the economy, but the distinguishing factor of their definitions of the economy is that on the one hand, Kautilya goes deep into explaining every factor that drives trade commerce and economy and on the other hand Adam smith goes on with a crisp definition. While at the age of Thiruvalluvar and David Ricardo India was still dependent on agriculture as their livelihood wherein western world had begun production and industries. Thus, their thoughts do not coincide at any point at all. Economists like Dadabhai Naroji had a clear difference between their primary thought of how Indian economy should have been and how it was due to western (British) draining the Indian economy. V.K.R.V Rao contradicts with John Maynard Keynes that Keynesian theory only focused on developed economies and never focused on underdeveloped economies where difference exists between income and consumption.

\section{CONCLUSION}

There is a great set of differences and similarities between two schools of thoughts, Current conceptual paper analyses handfew of fine economists of the same period and draws similarities and differences between their thoughts. Although there are deltas between thoughts, all economists' ultimate agenda remained the same viz to suggest theories and practices that would refuel the economy or continue the economy at the current pace. History and efforts of such economists have laid stronger foundations for future studies in economics and pave the way to analyze and improve the current perspective of trade, commerce, and economics.

\section{SOURCES OF FUNDING}

This research received no specific grant from any funding agency in the public, commercial, or not-for-profit sectors.

\section{CONFLICT OF INTEREST}

The author have declared that no competing interests exist.

\section{ACKNOWLEDGMENT}

None.

\section{REFERENCES}

[1] Boundless. (2018). Boundless World History. NewYork: Suny Press.

[2] Chandan R Honavar, K. B. (2020). APPLICATION OF FRAMING IN LEADERSHIP COMMUNICATION: A SYSTEMATIC REVIEW AND RESEARCH AGENDA (11 ed., Vol. 7). Bangalore, Karnataka, India: International Journal of Engineering Technologies and Management Research. doi:https://doi.org/10.29121/ijetmr.v7.i11.2020.817

[3] Dasgupta, A. K. (1993). A History of Indian Economic thought. London: ROUTLEDGE.

[4] Rana, D. S. (2013). Notions of Commerce in Ancient Indian Economic thought. International Journal of Advanced Research in Management and Social Sciences, 228-229.

[5] Rushton, A. O. (2004). The Handbook of Logistics and Distribution Management. London: Kogan Page. International Journal of Engineering Technologies and Management Research 
[6] The Arthashastra. (2010). Retrieved December 20, 2020, from Google Books website: https://books.google.co.in/books?hl=en\&lr=\&id=FFJz72h5qjUC\&oi=fnd\&pg=PP10\&dq=Arthashastra\&ots=1 2E34AMEA5\&sig=a8q_rh1rAGplgKmbBl7coqrarbw\&redir_esc=y\#v=onepage\&q=Arthashastra\&f=false

[7] The Wealth of Nations. (2010). Retrieved December 20, 2020, from Google Books website: https://books.google.co.in/books?hl=en\&lr=\&id=4HPdAgAAQBAJ\&oi=fnd\&pg=PP1\&dq=adam+smith+wealt $\mathrm{h}+\mathrm{of}+$ nations\&ots=yx5BLDgAUk\&sig=b6nkxTPx1nx8aKe4WXCxdMnY7vg\&redir_esc=y\#v=onepage\&q=ada $\mathrm{m} \% 20$ smith\%20wealth\%20of\%20nations\&f=false

[8] Chendroyaperumal, C. (2010). The First Laws in Economics and Indian Economic Thought - Thirukkural. S.S.R.N. Electronic Journal. https://doi.org/10.2139/ssrn.1545247

[9] The Works of David Ricardo. (2010). Retrieved December 20, 2020, from Google Books website: https://books.google.co.in/books?hl=en\&lr=\&id=hJ9RAAAAcAAJ\&oi=fnd\&pg=PR15\&dq=David+ricardo\&ots =tt0PHD23Gw\&sig=LQ33YOaS_FHris1Lt_dTQYxsXcw\&redir_esc=y\#v=onepage\&q=David\%20ricardo\&f=fals e

[10] Wage theory | economics | Britannica. (2020). In Encyclopædia Britannica. Retrieved from https://www.britannica.com/topic/wage-theory

[11] Dadabhai Naoroji. (2015). Poverty and un-British rule in India. Retrieved December 20, 2020, from undefined website: https://www.semanticscholar.org/paper/Poverty-and-un-British-rule-in-IndiaNaoroji/82f04c19824f8b65a939543b7583166db8d9941c\#paper-header

[12] Karl Marx. (2010). Retrieved December 20, 2020, from Google Books website: https://books.google.co.in/books?hl=en\&lr=\&id=yTWcAQAAQBAJ\&oi=fnd\&pg=PP2\&dq=Karl+marx\&ots=X aQUMf4Luh\&sig=6sq3U2KHsL0j2QR_N-jV3jNP46Q\#v=onepage \&q=Karl\%20marx\&f=false

[13] Rao, V. K. R. V. (1952). INVESTMENT, INCOME AND THE MULTIPLIER IN AN UNDERDEVELOPED ECONOMY. Indian Economic Review, 1(1), 55-67. Retrieved from https://www.jstor.org/stable/45149597?seq=1

[14] Skidelsky, R., Maynard, J., \& De Alcal\&amp;, U. (n.d.). E A ANTONIO TORRERO MAÑAS. Retrieved from http://revecap.com/revista/numeros/02/pdf/torrero.pdf

[15] Isher Judge Ahluwalia. (2012). India's economic reforms and development: essays for Manmohan Singh. Retrieved from https://econpapers.repec.org/bookchap/oxpobooks/9780198082231.htm

[16] Skousen, M. (2016). The making of modern economics: the lives and ideas of the great thinkers. Routledge. 